\title{
Analysis of Factors Influencing the Decision of Japanese Investors to Direct Investment in Thailand
}

\author{
Suntonwasit Kummanont \\ Industrial Business and Human Resource Development, King Mongkut's University of Technology North \\ Bangkok, 1518 Pibulsongkram road, Bangsue, Bangkok 10800, Thailand
}

\begin{abstract}
The report studies the key factors of Japanese investors who decide to invest in Thailand. Using direct survey of executives of Japanese companies in Thailand of 162 companies in all business groups, which consisted of seven groups. Metal and Machinery, Transportation and vehicle, Chemical, Paper and Plastic, Electronics, Electric appliances and Other industries group. Data was collected using a questionnaire to measure the level of satisfaction which uses a seven-point likert scale questions and the results were processed and analyzed exploratory factor Analysis and structural equation. The variable using observations from studies in the past were 23 variables comprising economic variables, government \& regulation and legal variables, Infrastructure variables, and the factors In terms of human resource.

The results showed that the structural equation model of factors critical to the investment of Japan in Thailand. Political and Economic Potential effects of the maximum. Followed by the Learning Growth and Long-term disaster Protection. Law, Regulation and Practicing and Infrastructure factor has no direct effect on of Japan's direct investment in Thailand however they were indirect representation.

When Kano's theory applied to the analysis of structural equation found. Performance dimension on theory of Kano that influence of Japanese direct investment in Thailand a rising were Reasonable wage, Economic and Exchange rates stability. Stable political. Logistics system efficiency. And the development of Long-term disaster protection. The factors that make Thailand is inviting and attractive for investment or Attractive dimension on Kano's Theory and it is different from other countries were develop The competition and modernized tax system as well as improving The standard of education.
\end{abstract}

Keywords: Analysis of factors influencing the decision, Japanese investors, Direct investment in Thailand

\section{Introduction}

It is well known over the past decade, Thailand's economic growth continuity. The GDP growth rates were high continuously that the key factor is foreign direct investment, especially investment industry (Jansen1995)As due from the country which are in developing level, lack of domestic saving, investment technology and the ability of enterprises.

As from the start of country development, the government has been launch the Investment law. After that the law has been amendment by Industrial Promotion Act 1954 and the Stamp Act to promote industrial investment in 1960, which is more complete. And also appointed "The Committee, promote industrial investment," which is the beginning of the Board of Investment of Thailand (BOI 2012), including a plan for economic development since the first edition 1961 (NESDB 1961)onwards, the area started to open and there are policies that encourage foreign direct investment clearly. Foreign direct investment has had to invest a lot. As analysis found the initial investment for production to replace imports from abroad (Viravan 1972) There are various empirical studies which show that there is positive relationship between FDI and economic growth and FDI is a key component of the world's growth engine, hence countries such as in Asia try to create favourable conditions to attract more FDI inflow into their economies. (Adhikary 2011; Bhavan et.al 2011; Azam 2010) The expansion of the foreign direct investment in Thailand has expanded to the industry with the export of goods to be sold abroad. As a result, the expansion of trade both within the country and abroad, and the rate of increase of exports at a high rate.(BOI 2012) 
Figure 1: Amount of foreign direct investment in Thailand from 2005 to2012

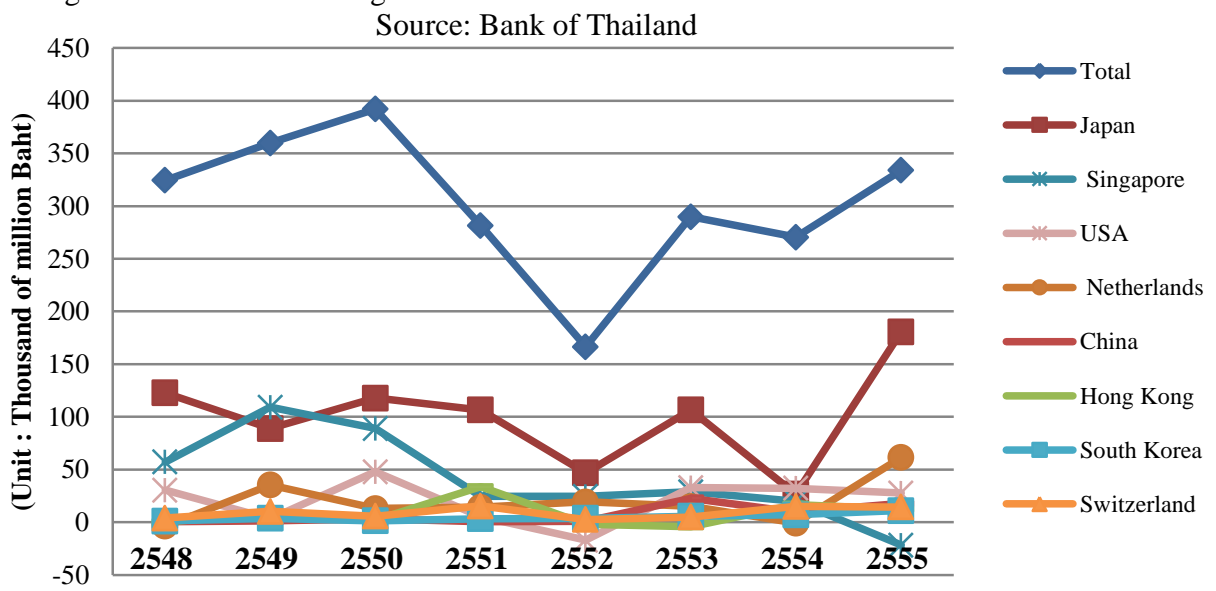

It is evident that foreign direct investment coming into the year from 2005 to 2012 as investments from Japan, most regularly. And if the sum of Japan direct investments in Thailand from 2005 to 2012(Fig.1) be worth 796,921 million baht in total investment value of foreign direct investment totaled 2,418,809 million baht, or about 33 percent of all foreign direct investment.

In particular, this study applies structural equation modeling (SEM) and Kano's Theory to investigate the factors of FDI from Japanese investors as sets of investment environmental factors, on the investment intention of doing business in Thailand. SEM has been widely used in a number of disciplines, including healthcare (Babakus and Mangold,1992),information management (Etezadi-Amoli and Farhoomand, 1996), logistics (Dunn et al., 1994; Stank et al., 2001; Lin et al., 2005), marketing(Steenkamp and Baumgartner, 2000), psychology (Agho et al., 1992; Shen et al., 1995), and tourism management (Reisinger and Turner, 1999). As similar to the Kano's theory that is used and accepted widely in Engineering, product design which is centered base on consumers or users value and the responses from the application will take the various views.

\section{Objective}

- To analyze the key factors that influence the investment decisions of Japanese investors to invest in Thailand.

- To study the emphasis of the human factor to consider direct investment from Japan.

- To create a model to explain the factors that affect of Japanese investors to invest in Thailand.

Figure 2: A conceptual model of the factors hypothezed of Japan direct investment in Thailand

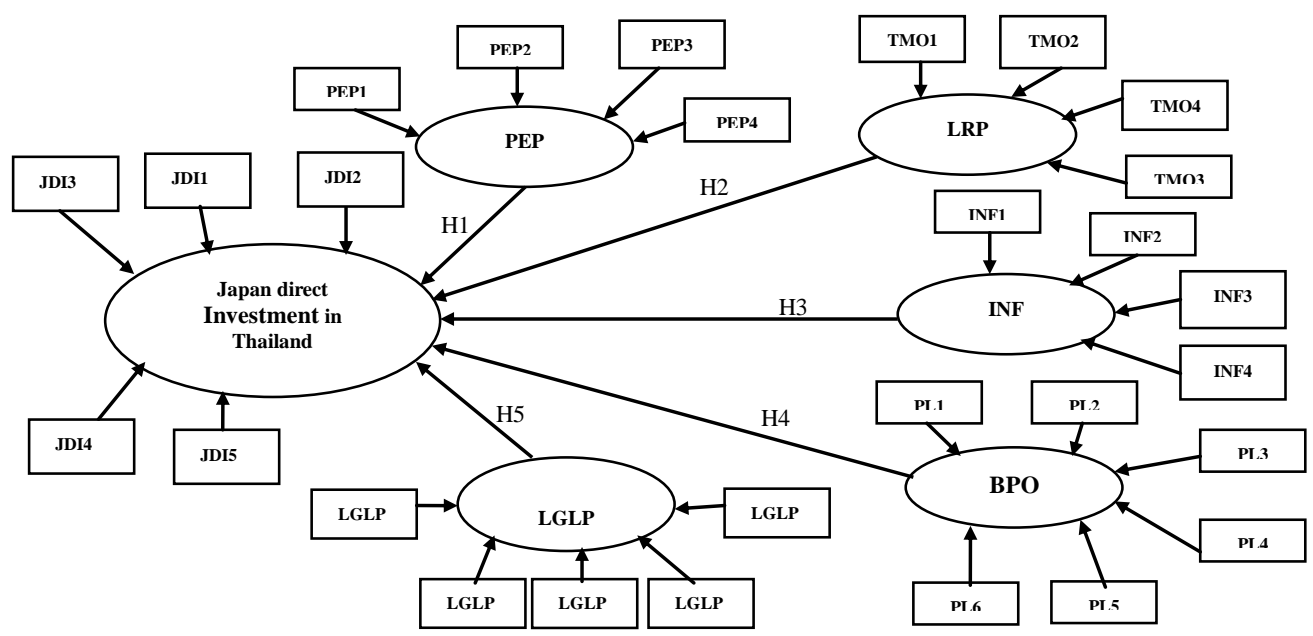

\section{Hypothesis}

H1. Factor of Political and Economic Potential (PEP) have a positive effect with Japan direct investment in Thailand.

A research report showed that the risk of major business for the decision to invest is risk of political stability (Moosa 2002) due to political risk can also be traced to problems in business concerning. It has severe 
effect as it can cause disruption or sales, or cause damage to investment in property or estates, Including the seizure of property by government officials (Daniels, et al. 2002) for the major political events that reflect the instability of government occurred as a revolution and a coup. It is found that the problem of political stability also occurred in developing countries.

H2. Factors of Law, Regulation and Practicing (LRP) have a positive effect with Japan direct investment in Thailand.

A research have advocated that countries with clear rules and practices to support foreign direct investment (Jadhav 2012), A study report in China found that bribery will result in negative foreign direct investment (Wei, 1999).

H3.Factor of Infrastructure (INF) have a positive effect with Japan direct investment in Thailand.

A study of the utility infrastructure as factors influencing foreign direct investment. It was found that the infrastructure are the key factors that cause foreign direct investment in Japan and the United States (Mody and Srinivasan 1998), In the emerging economies, many researchers who studied the factors of infrastructure that affecting the foreign direct investment. The report showed that the adequate and efficient infrastructure in China was the major cause of foreign direct investment.(LuMinghong 2000) In the same year, A study in China found the infrastructure sufficient helped to promoting FDI.(Zhao and Zhu 2000)

H4. Factor of Business Promotion and Openness (BPO) have a positive effect Japan direct investment in Thailand.

Tax privileges and liberalization of trade and investment in domestic and AEC member countries will cause market expansion which will be beneficial for the local and international companies who have operations in the region, The industry is pushing for a different continuity. (Mirza and Giroud, 2004) The benefits of the integration of the countries of Southeast Asia is making a market in a larger size in AEC community, which has a population of over 600 million people (Plummer 2009).

H5.Factor of Learning Growth and Long run Protection (LGLP) have a positive effect with Japan direct investment in Thailand.

The study is reported as an indicator that the human factor is the key factor to encourage foreign direct investment as educated workers and training are critical factors that cause direct investment, a study reported in the United States and Japan (Mody and Srinivasan 1998), corresponding study in China found the factors in education are critical factors affecting foreign direct investment (Bhagwati and Srinivasan 1983), As same as a study report in Nigeria found the education of worker was the major factors of FDI. (Akinlo 2004)

\subsection{Data collection}

\section{Research Methodologies}

Research using questionnaires to collect data from a sub-population with investors from Japan that was a business in Thailand as production facilities, services and others. Research tooling, Questionnaires have 2 parts with based on structural equation (1st part) and questionnaires based on the theory of Kano (2nd part) after assessed for validity and reliability through it. Its sent to the target demographic, Japanese companies in Thailand by using random alphabetical list of English alphabet (A-Z), using a total of 1,000 questionnaires by mail. The target were the highest ranking executive of Japanese companies, The Chief Financial Officer(CFO) which is responsible for the manage and control the investment and finance of company and knowledgeable about the investment policies. The company mainly targets the establishment or factory is located in Bang Pa -in Industrial Estate, Rojana Industrial Park, Hi-Tech Industrial Estate in Ayutthaya, Nava Nakorn Industrial Estate, Bang Kadi Industrial Park in Pathum Thani province, Industrial Estate in Samut Prakan, Amata Nakorn Industrial Estate in Cholburi and LatKrabang Industrial Estate in Bangkok and other operators which a service business almost of these establishments in Bangkok and nearly. The survey commenced on May1,2013 and end on May 30,2013 and was responded back from June to August2013 .

\subsection{Data Analysis}

The first part is the questionnaire by seven-points likert scale with answers categorized by level of satisfaction in seven levels to collect and analyze factors by exploratory factor analysis and structural equation analysis. The second part is the evaluation factors investors consider and use the theory of Kano consists of questions to be answered from a sense perception that has the answer as level of 1 to 5 for functional form question and answer as level of 1 to 5 for dysfunctional form questions as well, which is characteristic of the model based on the theory of Kano. The compile from Kano test should be wider dimension from the traditional answer. The collection and verification of data integrity. Then analyzed by means of descriptive statistics to analyze the data of the respondents. Conscious and quantitative to analyze the first part. By analyzing the factors with exploration factors and structural equation to analyze the structural equation model.

Data from the second part of the questionnaire was used to analyze the theory of Kano. Using tables to estimate responses to each question set by Kano's Evaluation Table (Maztler, K .et al. 1996) were organized into 
features in six features based. These include the Must-Be, Performance, Attractive, it's not different(InDifferent), the Question and the Reverse.

\begin{tabular}{|c|c|c|c|c|c|c|}
\hline \multicolumn{7}{|c|}{ Dysfunctional Form of Questions } \\
\hline \multirow{6}{*}{ 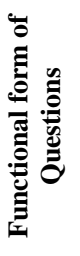 } & $\begin{array}{c}\text { Customer } \\
\text { Requirement }\end{array}$ & Like & Must-Be & Neutral & Live With & Dislike \\
\hline & Like & Q & A & A & A & $\mathrm{P}$ \\
\hline & Must-Be & $\mathrm{R}$ & $\mathrm{I}$ & I & I & $\mathrm{M}$ \\
\hline & Neutral & $\mathrm{R}$ & $\mathrm{I}$ & $\mathrm{I}$ & I & $\mathrm{M}$ \\
\hline & Live With & $\mathrm{R}$ & $\mathrm{I}$ & I & I & M \\
\hline & Dislike & $\mathrm{R}$ & $\mathrm{R}$ & $\mathrm{R}$ & $\mathrm{R}$ & $\mathrm{Q}$ \\
\hline
\end{tabular}

Table 1: Kano's Evaluation table

Depth interviews are done with agencies or individuals associated with the investment for consideration of additional analysis and for fruitful discussions.

Data were analyzed using descriptive statistics . Reliability analysis of cronbach's alpha coefficient and exploratory factor analysis. Using the Statistical Analysis, Statistical Package for the Social Sciences (SPSS) version 21 and application software as Analysis of Moment Structures(Amos) Version 21 in the structural equation analysis.

Figure 3: Process of structural equation Mythology

\section{Research tooling development}

- Literature review

- Theoretical basis

- Questionnaire design

- Evaluated of validity with 7 experts and 30 pilot companies

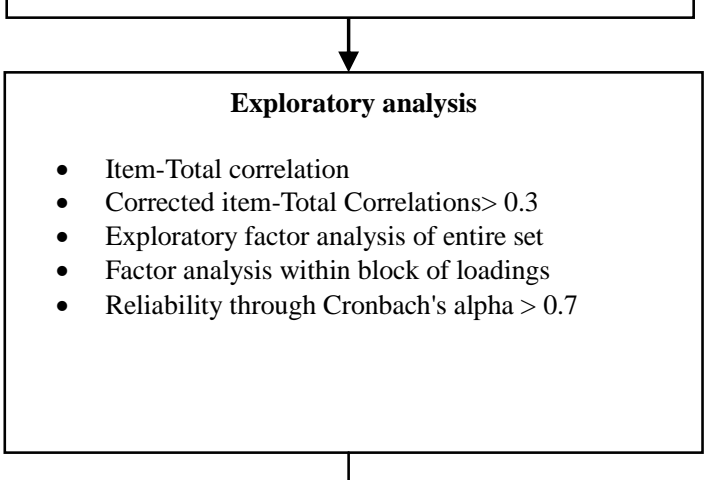

- Research tooling development

Analysis of the literature reviews that emphasis of foreign direct investment, which is collection from related study report in various countries.

Table 2 : FDI variables Evaluation from literature review

\begin{tabular}{|c|c|c|}
\hline Dimension & Attribute/Variable & Referred study of. \\
\hline \multirow[t]{5}{*}{ Economic } & As adequate of Raw material & $\begin{array}{l}\text { (BOI 2010) (BOI 2011) (Viravan 1972) (Jadhav, 2012) } \\
\text { (Aseidu 2005) (Dupasquier\&Osajwe 2006) (Deichmann et.al. 2003) }\end{array}$ \\
\hline & Optimum production cost & (BOI 2010) (BOI 2011) (Zhao and Zhu 2000) \\
\hline & Reasonable of labor cost & $\begin{array}{l}\text { (BOI 2010) (BOI 2011) (Trillit 1995) (Viravan 1972) } \\
\text { (Julian 2001) (Coughlin et al.1991) (Tsai 1994) }\end{array}$ \\
\hline & Stable of Economic & $\begin{array}{l}\text { (BOI 2010) (BOI 2011) (Fan and Dickie 2000) (Jadhav 2012) } \\
\text { (Athukorala\&Sen, 2002) (Pindyck\& Solimano1993)( Price 1995) }\end{array}$ \\
\hline & To manage currency exchange rate & (BOI 2010) (JCCB Survey 2012) (Wang \& Swain 1995) \\
\hline \multirow[t]{6}{*}{$\begin{array}{l}\text { Government/ } \\
\text { Regulation }\end{array}$} & Political stability & $\begin{array}{l}\text { (Daniels, et al.2002) (Jadhav 2012) (Dunning 1993)( Moosa 2002) } \\
\text { (Dupasquier\&Osajwe 2006) (Zenegnaw A.H.2010) }\end{array}$ \\
\hline & $\begin{array}{l}\text { Continual investment policy } \\
\text { (Promoted \& Incentive) }\end{array}$ & $\begin{array}{l}\text { (BOI 2010) (Yamagata 1998) (Julian 2001) } \\
\text { (Lall and Streeten 1977) ( Lall 1980) (Cave 1996) } \\
\text { (Woodward and Rolfe 1993) (Head and Ries 1996) }\end{array}$ \\
\hline & $\begin{array}{l}\text { Join with Asian Economic Community } \\
\text { (Market Size) }\end{array}$ & $\begin{array}{l}\text { (BOI 2010) (JCCB Survey 2012)(Mirza,Giroud 2004) (Plummer 2009) } \\
\text { (Blejer\& Khan 1984)( Sundarajan\& Thakur 1980) }\end{array}$ \\
\hline & $\begin{array}{l}\text { Transparent administration and good } \\
\text { governance }\end{array}$ & (BOI 2010) (Trillit 1995) (Jadhav 2012) (Smarzynska\& Wei 2002) \\
\hline & Clear modern tax system & (BOI 2010) (JCCB Survey 2013) \\
\hline & No limit percent of shareholders & (Yamagata 1998) \\
\hline
\end{tabular}




\begin{tabular}{|c|c|c|}
\hline & No limit the number staffs to work & (Hamada 1972) (Yamagata 1998) \\
\hline \multirow[t]{6}{*}{ Infrastructure } & Efficient logistic competitive & $\begin{array}{l}\text { (BOI 2010) (JCCB Survey 2013) (Mody and Srinivasan 1998) } \\
\text { (Zhao and Zhu 2000) (LuMinghong 2000) }\end{array}$ \\
\hline & Efficient supply chain system & (BOI 2011) \\
\hline & $\begin{array}{l}\text { Efficient telecommunication system with } \\
\text { reasonable price }\end{array}$ & (LuMinghong 2000) \\
\hline & System protection from natural disaster & $($ BOI 2010) (BOI 2011) \\
\hline & Adequate industrial zone & (JCCB Survey 2013) (Zhao and Zhu 2000) \\
\hline & $\begin{array}{l}\text { Efficient transport, adequate of power \& } \\
\text { water }\end{array}$ & $\begin{array}{l}\text { (JCCB Survey 2013) (Mody and Srinivasan 1998) ( Brainard 1993, 1997) } \\
\text { (Zhao and Zhu 2000) (LuMinghong 2000) (Coughlin et al.1991) }\end{array}$ \\
\hline \multirow{5}{*}{$\begin{array}{l}\text { Human } \\
\text { Resource }\end{array}$} & Sufficient skilled labor & (BOI 2010)(BOI 2011)(Mody and Srinivasan 1998)(Fan and Dickie 2000) \\
\hline & $\begin{array}{l}\text { Positive attitude toward foreign } \\
\text { investment }\end{array}$ & (AEIS 2012) \\
\hline & $\begin{array}{l}\text { Internal standards and have } \\
\text { opportunities to exploit knowledge into } \\
\text { real competitive edge }\end{array}$ & (JCCB Survey 2013) (Akinlo 2004) (Bhagwati and Srinivasan1983) \\
\hline & Foreign languages skill & (AEIS 2012) (JCCB Survey 2013) (LuMinghong 2000) \\
\hline & As continuous learning system & (JCCB Survey 2013) \\
\hline
\end{tabular}

From analytical process found 23 observed variables that consists of five factors.

- Exploratory Analysis

As from the result of descriptive analysis found the variables derived from data that are skewed slightly above the normal, As rang of $+1 /-1$ as only three variables and levels were not very high. As the kurtosis were within normal, range of $+3 /-3$ (Kline 2005) that only one was above and it little high.

Table 3 : Descriptive Statistics for Factors of Japan direct investment in Thailand

\begin{tabular}{|c|c|c|c|c|c|c|c|c|c|}
\hline \multicolumn{10}{|c|}{ Descriptive Statistics } \\
\hline & $\mathrm{N}$ & Minimum & Maximum & Mean & Std. Deviation & Skey & ness & & \\
\hline & Statistic & Statistic & Statistic & Statistic & Statistic & Statistic & Std. Error & Statistic & Std. Error \\
\hline AdeRawmat & 162 & 1 & 7 & 5.36 & 1.240 & -1.258 & 191 & 1757 & 379 \\
\hline OptimalPro & 162 & 1 & 7 & 5.14 & 1.360 & -.801 & .191 & -.133 & .379 \\
\hline Labor & 162 & 1 & 7 & 5.02 & 1.153 & -.788 & .191 & .070 & .379 \\
\hline StaEconomic & 162 & 3 & 7 & 5.58 & 1.008 & -.591 & .191 & .150 & .379 \\
\hline ExEfficiency & 162 & 3 & 7 & 5.13 & 1.180 & -.301 & 191 & -.728 & 379 \\
\hline StaPolitical & 162 & 2 & 7 & 4.82 & 1.383 & -.344 & .191 & -.739 & .379 \\
\hline InvestPolicy & 162 & 2 & 7 & 5.36 & 1.073 & -.831 & 191 & 1.288 & .379 \\
\hline AEC & 162 & 3 & 7 & 5.49 & .900 & -.506 & 191 & .635 & 379 \\
\hline Transparentgov & 162 & 1 & 7 & 5.26 & 1.559 & -.819 & 191 & .049 & 379 \\
\hline ModerntaxSystem & 162 & 1 & 7 & 5.51 & 1.186 & -.833 & .191 & .637 & .379 \\
\hline ShareholdersLimit & 162 & 3 & 7 & 5.68 & 1.055 & -.802 & 191 & .118 & .379 \\
\hline ForeignerstaffLimit & 162 & 3 & 7 & 5.55 & .885 & .039 & 191 & -.467 & .379 \\
\hline EfficientLogistic & 162 & 1 & 7 & 5.17 & 1.441 & -.939 & .191 & .267 & .379 \\
\hline EfficientSupply & 162 & 2 & 7 & 5.38 & 1.328 & -.978 & .191 & .397 & .379 \\
\hline EfficientTellecom & 162 & 1 & 7 & 5.34 & 1.087 & -1.327 & 191 & 3.584 & .379 \\
\hline DisasterProtect & 162 & 2 & 7 & 4.86 & 1.607 & -.111 & 191 & -1.163 & .379 \\
\hline PowerWater & 162 & 3 & 7 & 5.52 & 1.065 & -.847 & .191 & .401 & .379 \\
\hline IndustrialZone & 162 & 3 & 7 & 5.53 & .998 & -.807 & 191 & .771 & .379 \\
\hline SufficienSkillLabor & 162 & 2 & 7 & 5.36 & 1.298 & -.692 & .191 & -.018 & .379 \\
\hline PrositiveAttitude & 162 & 3 & 7 & 5.79 & 1.042 & -.769 & 191 & .328 & 379 \\
\hline StandardEduated & 162 & 1 & 7 & 5.12 & 1.422 & -1.284 & .191 & 1.485 & .379 \\
\hline ForeignerProficient & 162 & 1 & 7 & 4.60 & 1.488 & -.830 & 191 & .132 & .379 \\
\hline ConLerningSys & 162 & 2 & 7 & 5.08 & 1.405 & -.729 & .191 & -.257 & 379 \\
\hline Valid N (listwise) & 162 & & & & & & & & \\
\hline
\end{tabular}

Preceding of correlation matrix, they were generated from the specific variables to be imported into the analysis process when analyzing the factors, the step would analized by testing of KMO and Bartlett's Test of Sphericity before. the result was 0.79 , which is considered appropriate to be included as a factor, and the ability to perform the extraction, and after the process of extracted factors by Principle Component Analysis found that the major factors including 6 factors(Eigen value $>1$ ) as cumulative sum of squared loading of $77.05 \%$.

Table 4 : Principle component analysis for Factors of Japan direct investment in Thailand

\begin{tabular}{|c|c|c|c|c|c|c|}
\hline \multicolumn{7}{|c|}{ Rotated Component Matrix ${ }^{a}$} \\
\hline & \multicolumn{6}{|c|}{ Component } \\
\hline & 1 & 2 & 3 & 4 & 5 & 6 \\
\hline AdeRawmat & .194 & .069 & .109 & -.075 & .806 & .179 \\
\hline OptimalPro & .272 & .171 & .169 & .089 & .171 & .817 \\
\hline Labor & -.003 & .130 & .787 & -.326 & -.009 & .186 \\
\hline StaEconomic & .016 & .046 & .827 & .204 & .208 & -.289 \\
\hline ExEfficiency & .083 & .003 & .782 & .299 & .181 & .122 \\
\hline StaPolitical & .235 & -.096 & .821 & .107 & .136 & .225 \\
\hline InvestPolicy & .455 & .192 & .331 & .547 & .040 & .105 \\
\hline AEC & .085 & .055 & .267 & .666 & -.069 & .144 \\
\hline Transparentgov & .049 & .117 & .293 & .032 & .813 & .053 \\
\hline ModerntaxSystem & .054 & 149 & .584 & .331 & .504 & -.238 \\
\hline ShareholdersLimit & -.097 & .348 & .292 & .637 & .081 & -.045 \\
\hline ForeignerstaffLimit & .235 & .197 & -.295 & .675 & .178 & .038 \\
\hline EfficientLogistic & .098 & .842 & .097 & .204 & .238 & .177 \\
\hline EfficientSupply & .200 & .819 & -.029 & .241 & .325 & .140 \\
\hline EfficientTellecom & .209 & .839 & .041 & .099 & -.128 & .032 \\
\hline DisasterProtect & .789 & -.013 & .116 & .210 & .313 & .104 \\
\hline Powerwater & .555 & .595 & .024 & .184 & .106 & $\begin{array}{r}.704 \\
-.082\end{array}$ \\
\hline IndustrialZone & .434 & .472 & -.043 & .541 & -.119 & -.293 \\
\hline SufficienSkillLabor & .812 & .228 & .066 & .311 & -.067 & .190 \\
\hline PrositiveAttitude & .225 & .533 & .051 & .572 & -.083 & -.002 \\
\hline StandardEduated & .602 & .449 & -.083 & .145 & .214 & 411 \\
\hline ForeignerProficient & .762 & .152 & .013 & .097 & .250 & .381 \\
\hline ConLerningsys & .822 & 320 & 192 & -175 & -.081 & -160 \\
\hline
\end{tabular}


On the Correlation Matrix, it can be analyzed in each group as follows (Figure 1.)

- F1 = factor to the growth of learning and long-term protection (Learning Growth and Long-term Protection: LGLP), which relate with education. skill development and includes a plan for the long term protection .

- F2 = Infrastructure (Infrastructure: INF), which is a factor that includes the availability of adequate infrastructure and efficient. That are conducive to expansion.

- F3 = potential economic and political factors (Political and Economic Potential: PEP), which is a factor as well as the political and economic stability. To be a motivating factor causing more FDI .

- F4 = factor to promote investment and liberalization of Business (Business Promotion and Openness: $\mathrm{BPO}$ ), which are the factors that contribute to government policy and regulatory limitations. Including attitudes toward foreign direct investment .

- F5 = legal requirements and practice (Law, Regulation and Practicing: LRP) is a factor as relate with legal, regulation requirement such as duty, tax, transparency administration that effect with the burden cost of business and reduced competitiveness.

\section{Confirmatory and Model Testing}

When analyzed by structural equation to prove the model form that is acceptable to the empirical data or not. Found to have structural equation with empirical results follows

Figure 4 Structural Equation Model

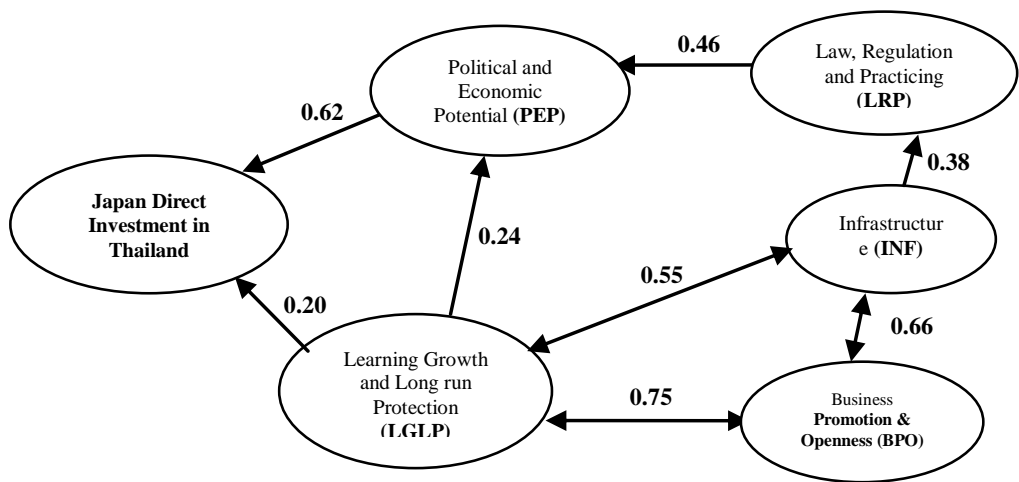

$\chi^{2}=665.899 \mathrm{DF}=256, \mathrm{P}$ Value $=0.00, \mathrm{RMSR}=0.131, \mathrm{RMSEA}=0.10, \mathrm{NFI}=0.84 \mathrm{CFI}=0.89$

Table 5 : Regression weight of each latent veritable in Structural Equation Model

\begin{tabular}{|c|c|c|c|}
\hline Constructs & Indicators & Scale Item & Factor Loading \\
\hline \multirow{5}{*}{$\begin{array}{l}\text { Learning Growth and Long } \\
\text { run Protection }\end{array}$} & LGLPI & Sufficient skilled-labor & 0.92 \\
\hline & $L G L P 2$ & English/Japanese proficiency & 0.82 \\
\hline & $L G L P 3$ & Continuous learning system & 0.67 \\
\hline & LGLP4 & International standard education & 0.76 \\
\hline & $L G L P 5$ & Natural disaster protection & 0.73 \\
\hline \multirow[t]{4}{*}{ Infrastructure } & INF1 & Efficient telecommunication system with reasonable price & 0.78 \\
\hline & INF2 & Efficient transportation system and adequate of power and water supply & 0.56 \\
\hline & INF3 & Efficient logistic & 0.83 \\
\hline & INF4 & Efficient supply chain system & 0.85 \\
\hline \multirow{4}{*}{$\begin{array}{l}\text { Political and Economic } \\
\text { Potential }\end{array}$} & $P E P I$ & Political Stability & 0.87 \\
\hline & $P E P 2$ & Currency exchange Stability & 0.80 \\
\hline & PEP3 & Reasonable cost of labor & 0.59 \\
\hline & PEP4 & Stable Economic & 0.53 \\
\hline \multirow{6}{*}{$\begin{array}{l}\text { Business Promotion and } \\
\text { Openness }\end{array}$} & BPOI & Continual Investment Policy & 0.59 \\
\hline & BPO2 & Member countries of Asian Economic Community (AEC) & 0.18 \\
\hline & BPO3 & Limit the number of foreign staffs to work in its territory & 0.55 \\
\hline & BPO4 & Adequate industrial zone & 0.79 \\
\hline & BPO5 & positive attitude towards foreign investors & 0.72 \\
\hline & BPO6 & $\begin{array}{l}\text { limit percentage of shares that can be held by foreigners in an } \\
\text { organization }\end{array}$ & 0.63 \\
\hline \multirow{4}{*}{$\begin{array}{l}\text { Law regulation and Good } \\
\text { Practicing }\end{array}$} & LRPI & Transparent administration and good governance & 0.90 \\
\hline & $L R P 2$ & Modern Tax System & 0.36 \\
\hline & $L R P 3$ & Optimal production cost & 0.65 \\
\hline & LRP4 & Adequate Raw material & 0.19 \\
\hline \multirow{5}{*}{$\begin{array}{l}\text { Japan Direct Investment in } \\
\text { Thailand }\end{array}$} & $J D I 1$ & Consider invest in Thailand as near future & 0.21 \\
\hline & $J D I 2$ & A tendency to do medium and long term investment in Thailand & 0.29 \\
\hline & $J D I 3$ & Increase production capacity, New project Thailand has the first reference & 0.85 \\
\hline & JDI4 & Thailand is the best candidate for investment in Asia & 0.81 \\
\hline & $J D I 5$ & $\begin{array}{l}\text { You have heard of great investment success, excellence operation } \\
\text { performance by Japan companies who has operated in Thailand }\end{array}$ & 0.37 \\
\hline
\end{tabular}


As from the result of the correlation analysis. The correlation coefficient between Efficiencylogistic (INF3) and EfficiencySupply (INF4) that correlation coefficient greater than 0.8 is considered to be a single observed variable as Efficiencylogistic for reducing of multi-collinearity effect. As Figure.4, latent factor of Business Promotion \& Openness was not the direct effect with Japan direct investment in Thailand, hence that it was reduced.

\section{Demographic Analysis}

\section{Findings}

As questionnaires sent to a total of 1,000 copies were responded 162 a total of 16.2 percent of all. A small business with total sales of 100 to 500 million baht and medium size businesses with sales of 1,000 to 5,000 million baht, total 94 companies as accounted for 58 percent. A data found that the group of electronics as 42 companies accounted for 25.9 percent, metals and machinery as 28 companies accounted for 17.3 percent. They invest in Thailand for a period of 16 to 30 years as 74 companies, representing 46 percent, with a business operating a joint venture as of 29 companies representing 18 percent, acquisitions of 19 companies accounted for 11.7 percent, the form of alliances 18 companies accounted for 11.1 percent. The company with a number of employees from 51 to 300 people, the highest number of 57 companies, or 35.2 percent.

\section{Structural Equation Mode}

After received the questionnaires, when the effect reliable analysis found, the first part of questionnaires, structural equation base has cronbach's alpha coefficient of 0.91 , which is acceptable. As exploratory factor analysis when applied with analysis of structural equation model showed that the developed model is consistent with empirical data. Basis by $\chi^{2}=146.275, \mathrm{DF}=89, \mathrm{P}$-value $=0.00, \mathrm{RMSR}=0.07, \mathrm{RMSEA}$ $=0.06, \mathrm{GFI}=0.92, \mathrm{NFI}=0.94, \mathrm{CFI}=0.98$ by a factor latency correlated with FDI of Japan, the number four factors and 15 observed variables on all.

Figure 5 Structural Equation Model as status of FIT

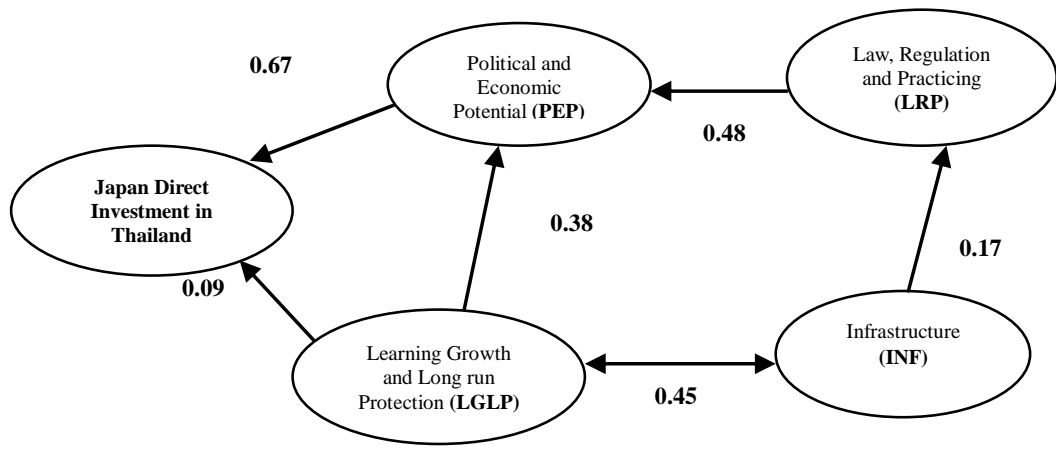

Table 6 : Regression Weight for Final of Structural Equation Model

\begin{tabular}{clll}
\hline Constructs & Indicator & Scale Item & Factor \\
Loading
\end{tabular}

\section{Hypothesis Test}


assumptions testing as table below.

Table 7 : The result of Hypothesis test

\begin{tabular}{|c|c|c|c|}
\hline Hypothesis & Relation & Coefficient(t- Value) & Result \\
\hline H 1 & $P E P \longrightarrow J D I$ & $0.669(7.009) * * *$ & Support \\
\hline$H 2$ & $L R P \longrightarrow J D I$ & $-0.194(-1.528)$ & Reject \\
\hline H 3 & $I N F \longrightarrow J D I$ & $-0.589(-2.016)^{* *}$ & Reject \\
\hline H4 & $\mathrm{BPO} \longrightarrow$ & $-0.504(-3.572) * * *$ & Reject \\
\hline H 5 & $L G P L^{-}$ & $0.094(1.186)$ & Support \\
\hline
\end{tabular}

Only two latent factors, Political and Economic Potential( PEP) and Learning Growth and Long-term Protection (LGLP) are positive effect with Japan direct investment in Thailand.

\section{Applied Kano's Theory}

As the second part of questionnaires base on Kano's theory, which includes as functional and dysfunctional form, when the effect reliable analysis has cronbach's alpha coefficients was 0.89 and 0.91 , which is acceptable. The result from the Kano surveyed as the follow

Table 8 : Result of Kano's Theory Surveyed

\begin{tabular}{|c|c|c|c|c|c|c|c|c|}
\hline Observed variables /Attributes & 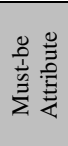 & 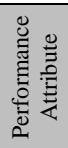 & 总总 & 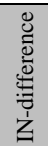 & 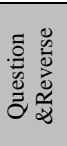 & $\stackrel{\infty}{: \infty}$ & $\stackrel{\Xi ّ}{0}$ & 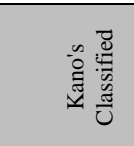 \\
\hline \multicolumn{9}{|l|}{ 1. Political \& Economic Potential: PEP 4 Attributes } \\
\hline -Political Stability & 20 & 70 & 5 & 56 & 10 & 1 & 162 & Performance \\
\hline -Stability of currency exchange rate & 17 & 65 & 20 & 54 & 5 & 1 & 162 & Performance \\
\hline -Reasonable cost of labor & 9 & 65 & 30 & 57 & 0 & 1 & 162 & Performance \\
\hline -Stable Economic & 20 & 60 & 25 & 51 & 5 & 1 & 162 & Performance \\
\hline \multicolumn{9}{|l|}{$\begin{array}{l}\text { 2. Learning Growth and Long run Protection : LGLP } 5 \\
\text { Attributes }\end{array}$} \\
\hline -Sufficient skilled-labor & 12 & 44 & 12 & 83 & 5 & 6 & 162 & Indifferent \\
\hline -English/Japanese proficiency & 0 & 34 & 30 & 92 & 0 & 6 & 162 & Indifferent \\
\hline -Continuous learning system & 5 & 29 & 30 & 92 & 0 & 6 & 162 & Indifferent \\
\hline -International standard education & 0 & 24 & 92 & 40 & 0 & 6 & 162 & Attractive \\
\hline -Natural disaster protection & 20 & 57 & 30 & 39 & 10 & 6 & 162 & Performance \\
\hline $\begin{array}{l}\text { 3. Law Rule and practicing :LRP } 4 \text { Attributes } \\
\text {-Transparent administration } \\
\text { and good governance }\end{array}$ & 24 & 45 & 20 & 72 & 0 & 1 & 162 & Indifferent \\
\hline -Modern Tax System & 10 & 66 & 70 & 10 & 0 & 6 & 162 & Attractive \\
\hline -Optimal production cost & 63 & 32 & 15 & 46 & 5 & 1 & 162 & Must-Be \\
\hline -Adequate Raw material & 39 & 33 & 17 & 63 & 9 & 1 & 162 & Indifferent \\
\hline \multicolumn{9}{|l|}{ 4. Infrastructure :INF 4 Attribute } \\
\hline -Efficient logistic & 15 & 61 & 35 & 45 & 0 & 6 & 162 & Performance \\
\hline -Efficient Telecommunication & 11 & 34 & 21 & 85 & 5 & 6 & 162 & Indifferent \\
\hline $\begin{array}{l}\text {-Efficient Transport and Adequate power and water } \\
\text { supply }\end{array}$ & 46 & 44 & 20 & 36 & 10 & 6 & 162 & Must-Be \\
\hline -Efficient Supply chain & 8 & 29 & 28 & 86 & 5 & 6 & 162 & Indifferent \\
\hline $\begin{array}{l}5 \text { Business Promotion and Openness: BPO } 6 \text { Attribute } \\
\text {-Continual Investment Policy }\end{array}$ & 15 & 43 & 42 & 61 & 0 & 1 & 162 & Indifferent \\
\hline -Member of AEC & 4 & 20 & 20 & 117 & 0 & 1 & 162 & Indifferent \\
\hline -Limit Foreigner for held shareholder & 7 & 19 & 37 & 93 & 5 & 1 & 162 & Indifferent \\
\hline -Adequate Industrial Zone & 21 & 34 & 16 & 80 & 5 & 6 & 162 & Indifferent \\
\hline -Positive Attitude toward Foreigner investor & 15 & 19 & 35 & 87 & 0 & 6 & 162 & Indifferent \\
\hline -Limit number of Foreign Staff in Workplace & 16 & 19 & 21 & 80 & 25 & 1 & 162 & Indifferent \\
\hline
\end{tabular}




\section{Discussions}

As respond from the first questionnaires survey on the factor analysis. And the structural equation model analysis showed that the improved model is consistent with empirical data . Basis by $\chi^{2}=146.275, \mathrm{DF}$ $=89, \mathrm{P}$-value $=0.00, \mathrm{RMSR}=0.07, \mathrm{RMSEA}=0.06, \mathrm{GFI}=0.92, \mathrm{NFI}=0.94, \mathrm{CFI}=0.98$ by a factor latency correlated with FDI of Japan, the number four factors and variables. observed on all 15 observed variables and analysis of results can be summarized as follows .

* Of structural equation model showed that the factors that most directly affect the investment of Japan in Thailand is the potential economic and political (PEP) effects of the maximum of 0.67, Second is about learning and growth and long-term protection factor (LGPL). As a result, Japan's direct investment in Thailand was 0.09 , the legal and regulatory factors, and other factors do not direct affect, but they have an indirect effect.

* This study found that factors related to human resources, which is the element of passive learning, growth factors and long-term protection. Is important to consider the investment of Japan in Thailand. The direct effect is 0.09 and It indirect effect through the potential economic and political factors as well.

* Factor theory of Kano. Which includes the value of core three factors is the underlying values Must Be, Performance, and Attractive have a positive effect on the share of investors from Japan to invest in Thailand.

\section{Acknowledgment and Recommendations}

As from research resulting, it can guide of format policies from related parties to support. Related to enhance the promotion of foreign investment, which will guide the redevelopment, economic development. It's the investment will make our economic expansion, higher employment levels, and also to develop quality human resources, which causes the value added in the economy and led to the development of society. There are lessons which suggests that foreign direct investment is a major part to make this happen, which to live, but only internal invest in countries where there is a dearth of the savings, expertise and quality of population the development is going to be limited. Examples of countries that have been successful outcome of such a policy of promoting foreign direct investment are South Korea, Taiwan and Singapore, where the first phase of developing countries had policies to promote foreign investment. Since they were country with shortage of natural resources, science and technology and savings, Internal market is quite small and but the policy of promoting foreign direct investment with strengths in low labor cost was the factor, human resources can learn and develop and support from the policies of the government concentrated. As now from success to develop the potential of the country had became the country with the potential for competition. It also has the potential to develop the technology by itself. And have sufficient funds to invest in domestic and aboard, change roles on a new group of potential investors .

\section{References}

[1]. Adhikary, B.K. (2011). "FDI, Trade Openness, Capital Formation, and Economic Growth in Bangladesh: A Linkage Analysis", International Journal of Business and Management, 6(1)

[2]. Athukorala, P., \&Sen, K. (2002). "Saving, investment and growth in India", Oxford: Oxford University Press.

[3]. Akinlo, A. (2004) "Foreign direct investment and growth in Nigeria: an empirical investigation”,Journal of Policy Modeling. 26 (5), 627-39.

[4]. Alam, Abdullah and Ali Shah. "Determinants of foreign direct investment in OECD member Countries",Journal of Economic Studies. 40 (4) (2013) : 515-527.

[5]. Asiedu, E., ( 2005). "Foreign Direct Investment in Africa: The Role of Natural Resources, Market Size, Government Policy, Institutions and Political Instability", working paper. United Nations University.

[6]. Azam, M. (2010). "An Empirical Analysis of the Impacts of Exports and Foreign Direct Investment on Economic Growth in South Asia, Interdisciplinary”, Journal of Contemporary Research in Business, 2(7)

[7]. Blejer, M. I., \& Khan, M. S. (1984). "Government policy and private investment in developing countries",IMF Staff Papers, 31(2), 379-403.

[8]. Brainard, S. Lael, 1993. "A simple theory of multinational corporations and trade with a trade-off between proximity and concentration",Working paper No. 4269. NBER.

[9]. Brainard, S. Lael, 1997. "An empirical assessment of the proximity concentration trade-off between multinational sales and trade", American Economic Review 87, 520-544.

Bank of Thailand : BOT.Foreign Direct investment by Country.[Online] 2012.[Cited 2012 Jan.]. Available from : URL :http://www.bot.or.th/Thai/Statistics/ ContactPerson/Pages/Contact.aspx

[10]. Bhagwati, J.N. and Srinivasan, T.N. (1983)Lectures in International Trade. Cambridge, MA : MIT Press.

[11]. Bhavan, T., Xu, Changsheng.,\&Zhong, C. (2011). "Determinants and Growth Effect of FDI in South Asian Economies:Evidence from a Panel Data Analysis", International Business Research. 4(1)

[12]. Caves, Richard E., 1996. "Multinational Enterprise and Economic Analysis", Cambridge Univ. Press, Cambridge,UK

[13]. Caves, Richard E. "International Corporations: The Industrial Economics of Foreign Investment",

Economica New Series. 38 (149) (Feb 1971) : 1-27.

[14]. Coskun, Recai. "Determinants of Direct Foreign Investment In Turkey", European Business Review. 13 (4) (2001) : $221-226$. 
[15]. Coughlin, C.C., Terza, J.V. and Arromdee, V. (1991) "State characteristics and the location of foreign direct investment within the United States",Review of Economics and Statistics.73 (4), 675-83.

[16]. Daniels, J.D., Radebaugh , L.H. and Sullivan, D.P.(2002) Globalization and Business, (1st Eds.). Upper Saddle River, New Jersey : Prentice Hall.

[17]. Deichmann, J.I., Eshghi, A., Haughton, D.M., Sayek, S., \&Teebagey. N.C. (2003), "Foreign direct investment in the Eurasian transition states". Eastern European Economics.41(1), 5-34

[18]. Dunning, J.H. (1993). "Multinational Enterprises and the Global Economy”, Addison-Wesley Publishing Company: Reading, MA

[19]. Dunning, J. H. (1988) "The Eclectic Paradigm of International Production: A Restatement and Some Possible Extensions", Journal of International Business Studies. 19 (1), 1-31.

[20]. Dupasquier,C., \&Osajwe,P.N. (2006). "Foreign direct investment in Africa: Performance, challenges, and responsibilities", Journal of Asian Economics., 17 (2), 241-260

[21]. Fan, X. and Dickie, P.M. "The contribution of foreign direct investment to growth and Stability", ASEAN Economic Bulletin.(3) 17((2000: .312

[22]. Federation of Japanese Chambers of Commerce and Industry in ASEAN (FJCCIA). The Japanese Business Community Dialogue. [online] 2013. [cited 2013 Nov]. Available from : URL : http://www.asean.org/news/aseansecretariat-news/item/6th-asean-secretary- general-and-the-japanese-business-community-dialogue

[23]. Hair, J.F., et al. (1998) Multivariate data analysis. $5^{\text {th }}$ ed. Upper Saddle River : NJ. Prentice Hall,

[24]. Hamada, Koichi. (1972) Japanese Investment Abroad. Canberra : Australian National University Press.

[25]. Hatem, F.International Investment: Towards the Year 2001. New York : [n.p.], 1997.

[26]. Head, Keith, Ries, John, 1996. "Inter-city competition for foreign investment: Static and dynamic effects of China'sincentive areas",Journal of Urban Economics. 40, 38-60.

[27]. Hymer, S. H. "The International Operations of National Firms: A Study of Direct Foreign Investment", PhD Dissertation. Published posthumously. The MIT Press, 1976. Cambridge, Mass, 1960

[28]. Jadhav, Pravin. (2012)Determinants of Foreign Direct Investment In BRICS: Analysis of Economic, Institutional and Political Factor. New Delhi : Indian Institute of Foreign Trade.

[29]. Julian, Craig C. (2001) "Japanese foreign direct investment in Thailand",The Mid-Atlantic Journal of Business. 37 (1), 37.

[30]. Jansen, Karel. (1995) "The Macroeconomic effects of Direct Foreign Investment: The Case of Thailand”, World Development. 23 (2), 193-210.

[31]. Japanese Chamber of Commerce, Bangkok. JCCB SURVEY 2012. [online] 2012. [cited 2013 Jan]. Available from : URL : http://www.jcc.or.th/index.php?easiestml_lang=th

[32]. Japanese Chamber of Commerce, Bangkok. JCCB SURVEY 2013. [online] 2013. [cited 2013 Aug]. Available from : URL : http://www.jcc.or.th/index.php?easiestml_lang=th

[33]. Kagami, Mitsuhiro, Humphery, John and Piore, Micheal. Learning, Learning Liberalization and Economic Adjustment. Tokyo : Institution of Development Economies, [n.d.]

[34]. Kano, Noriaki, et al."Attractive quality and must-be quality", Journal of the Japanese Society for Quality Control (in Japanese). 14 (2) (1984) : 39-48.

[35]. Kindleberger, Charles P. American business abroad; six lectures on direct investment New Haven :Yale University Press, 1969.

[36]. Kojima, Kiyoji.Direct Foreign Investment; A Japanese Model Of Multinational Business Operations. New York :Praeger Publishers, 1978

[37]. Lall, Sanjaya, Streeten, Paul, 1977. "Foreign Investment, Transnationals and Developing Countries”,Macmillan.London.

[38]. Lall, Sanjaya, 1980.“ The Multinational Corporation”, Macmillan, London.

[39]. LuMinghong, M. (2000)The Locational Determinants of Foreign Direct Investment. [n.p.] : Nanjing University Press.

[40]. Maztler, K. and Hinterhuber, H.H. (1988) "How to make product development projects more successful by integrating Kano's model of customer satisfaction into quality function deployment", Technovation. 18 (1), 25-38.

[41]. Maztler, K., et al. (1996) "How To Delight Your Customers",Journal of Product \& Brand Management. 5 (2), 6-18.

[42]. Mirza, Hafiz and Giroud, Axele.(2004) "Regional Integration and Benefit from Foreign Direct Investment in Asian Economic: The Case of Vietnam",Asian Development Review. 21 (1), 66-98.

[43]. Mody, A. and Srinivasan, T.N.(1998) "Japanese and US firms as foreign investors: do they march to the same tune?", Canadian Journal of Economics. 31 (4), 778-99.

[44]. Moosa, I.A.(2002FDI: Theory, Evidence and Practice. New York : Palgrave.

[45]. Office of the National Economic and Social Development Board: NESDB.National Economic and Social

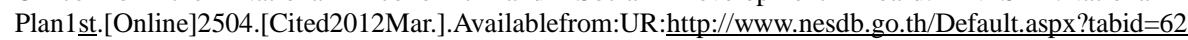

[46]. Plummer, Michael G.(2009) "Asian Economic Integration: Trade Foreign Direct Investment and Finance”, World Scientific. 6 .

[47]. Pindyck, P. C. B., \&Solimano, A. (1993). “Economic instability and aggregate investment”, NBER macroeconomics annual 1993. Cambridge: MIT Press.

[48]. Price, S. (1995). “Aggregate uncertainty, capacity utilization and manufacturing investment”, Applied Economics,57(2), $147-154$.

[49]. Smarzynska, B. K., \& Wei Shang-Jin. (2002). "Corruption and cross-border investment: firm-level evidence",William Davidson Institute Working Paper No. 494:1-29.

[50]. Sun, Q., Tong, W. and Yu, Q. "Determinants of foreign direct investment across China",Journal of International Money and Finance.21 ((2002:.113-79

[51]. Sundarajan, V., \& Thakur, S. (1980). "Public investment, crowding out, and growth: A dynamic model applied to India and Korea", IMF Staff Papers, 27(4),814-855.

[52]. The Board of Investment of Thailand :BOI. History.[Online] 2012.[cited 2012 Mar.]. Available from : URL :http://www.boi.go.th/index.php?page=our_history

[53]. The Board of Investment of Thailand : BOI. Study and Analysis of the foreign Investor Confidence in Thailand 2010 (SAFICT). Bangkok : [n.p.], 2010.

[54]. The Board of Investment of Thailand : BOI. Study and Analysis of the foreign Investor Confidence in Thailand 2011 (SAFICT). Bangkok : [n.p.], 2011.

[55]. The Economist. Social unrest. [online] 2013. [cited 2013 June]. Available from : URL :

http://viewswire.eiu.com/site_info.asp?info_name=social_unrest_table\&page=noads\&rf $=0$

[56]. The Association Of Electronic Industries In Singapore :AEIS.“Asian Manufacturing Forum 1.(AESI Forum)",The Nation Newspaper,(March12,2012) : 5 
[57]. The South Center. Development and The New Global Economic Order: A Policy Brief for The South. Geneva : [n.p.], 1997.

[58]. Tradingeconomics. Thailand Unemployment Rate. [online] 2013.[cited 2013 Oct]. Available from :http://www.tradingeconomics.com/thailand/unemployment-rate

[59]. Trillit,Viwat.(1995) "Factors encouraging and discouraging foreign direct investment in Thailand by multinational companies From USA, Japanese, Europe", DBA, Thesis. United states international university.

[60]. UNCTAD. "World Investment Report 2007: Transnational Corporations, Extractive Industries and Development.[online] 2007. [cited 2013 Mar]. Available from : URL : http://unctad.org/en/Pages/DIAE/World\%20Investment\%20Report/WIR-Series.aspx

[61]. Vernon, Raymond."International Investment and International Trade in the Product Cycle", Quarterly Journal of Economics.(1966) : 191.

[62]. Viravan, Amnuay.(1972) "Foreign Investment in Developing Countries: Thailand", Canberra : Australian National University Press.

[63]. Wang, Z.Q. and Swain, N.J. (1995) "The determinants of foreign direct investment in transforming economies: evidence from Hungary and China.”,WeltwirtschaftslichesArchiv.131((1995: .82-359

[64]. Wei, S.(1999) "Whether corruption affects FDI." working paper. National Centre for Economic Research.

[65]. Wheeler, D. and Mody, A. "International investment location decisions: the case of US Firms", Journal of International Economics.33(1992): .76-57

[66]. Woodward, Douglas P., Rolfe, Robert J., 1993. "The location of export-oriented foreign direct investment in the Caribbean basin",Journal of International Business Studies 24, 121-144.

[67]. World bank. Logistic Performance Index LPI result. [online] 2012. [cited 2013 Oct]. Available from : URL : http://lpi.worldbank.org/

[68]. Wu, Hsin-Hung. "A Case Study of Applying Kano's Model and ANOVA Technique in Evaluating Service Quality Information",Information Technology Journal. 10 (2010) : 89-97.

[69]. Yamagata, Tatsufumi. (1998) "Ineffective Protection, Weak linkage and poor performance: the Philippine and Thai textile industries",Learning liberal and economic adjustment, 33-35.

[70]. Zenegnaw, A.H. (2010). "Impact of Foreign Direct Investment on Trade of African Countries", International Journal of Economics and Finance 2(3)

[71]. Zhao, H. and Zhu, G.(2000) "Location factors and country-of origin differences: an empirical analysis of FDI in China", Multinational Business Review. 8 (1), 60. 